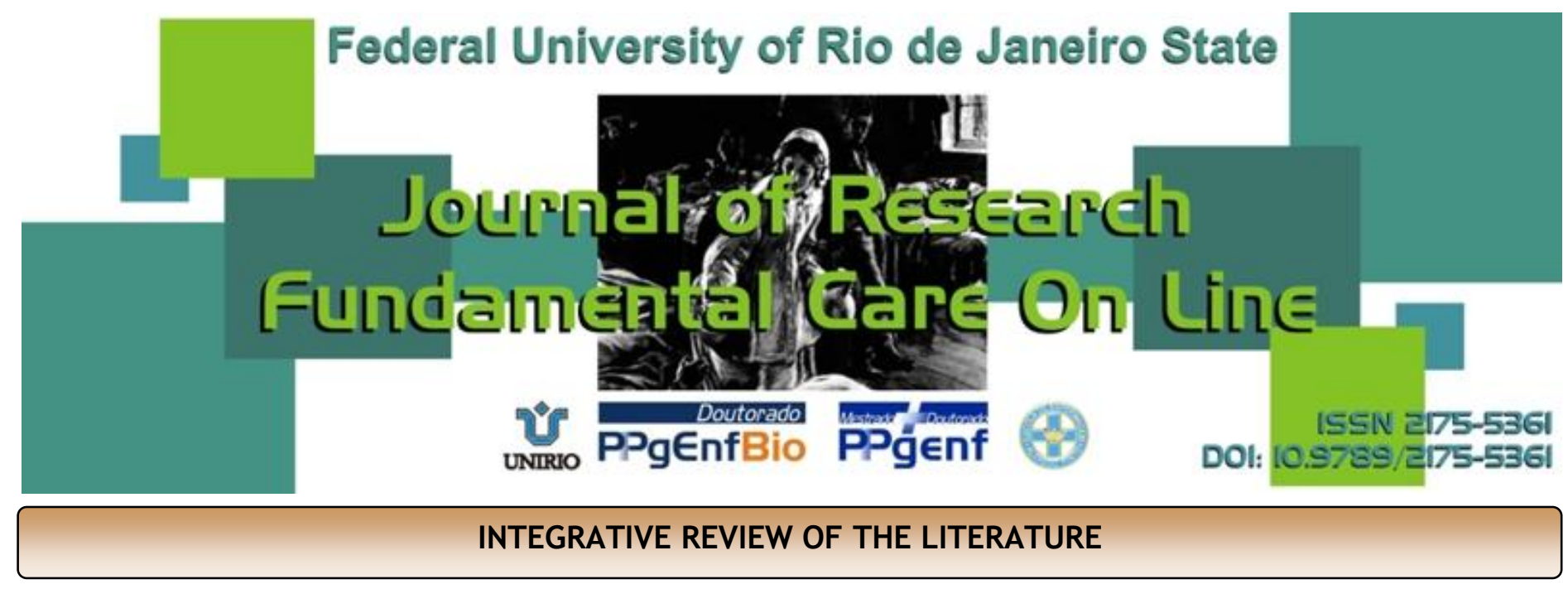

\title{
CONTINUING/PERMANENT EDUCATION AS A STRATEGY FOR MANAGING OF NURSING IN THE UNIQUE
} HEALTH SYSTEM: AN INTEGRATIVE REVIEW

EDUCAÇÃO CONTINUADA/PERMANENTE COMO ESTRATÉGIA NO GERENCIAMENTO DE ENFERMAGEM NO SISTEMA ÚNICO DE SAÚDE: UMA REVISÃO INTEGRATIVA

\section{LA EDUCACIÓN CONTINUA / PERMANENTE COMO UNA ESTRATEGIA PARA LA GESTIÓN DE ENFERMERÍA EN EL} SISTEMA ÚNICO DE SALUD: UNA REVISIÓN INTEGRADORA

Bruna Maiara Ferreira Barreto ${ }^{1}$, Daniel do Nascimento Tavares ${ }^{2}$, Juliana de Lima Brandão ${ }^{3}$, Juliana Cristina Pacheco Gonçalves ${ }^{4}$, Geilsa Soraia Cavalcanti Valente ${ }^{5}$, Francisco das Chagas Ferreira ${ }^{6}$

\begin{abstract}
Objective: To analyze the publications that focus on the process of continuing education in nursing in the period from 2008 to 2011. Method: integrative review conducted in Databases Virtual Health Library (Lilacs and SciELO), with the following inclusion criteria: having regard to its purpose; publication year from 2008 to 2011, addressing the issue of continuing education within the nursing; having the text available on line; language in English, Portuguese or Spanish. Results: After the search, were analyzed and categorized nine articles. Conclusion: it was realized that the challenges and actions by the multidisciplinary team at present are related to the lack of incentive shares of Continuing Education. Within the Nursing are even more essential these actions, as observed in everyday life, problems arising from lack of updating and training, directly implying a decrease in the yield of the quality of health care. Descriptors: Continuing education in nursing, Public health nursing.
\end{abstract}

\section{RESUMO}

Objetivo: analisar as publicações que enfocam o processo de Educação continuada no âmbito da enfermagem, no período de 2008 a 2011. Método: revisão integrativa realizada nas Bases de Dados da Biblioteca Virtual da Saúde (Lilacs e Scielo), com os seguintes critérios de inclusão: possuir relação ao objetivo proposto; ano de publicação de 2008 a 2011 ; abordar a temática de educação continuada no âmbito da Enfermagem; possuir o texto na íntegra disponível on line; idioma em português, inglês ou espanhol. Resultados: Após a busca, foram analisados e categorizados nove artigos. Conclusão: percebeu-se que os desafios e ações por parte da equipe multiprofissional na atualidade estão relacionados à carência de incentivo às ações de Educação continuada. No âmbito da Enfermagem são ainda mais imprescindíveis essas ações, pois observa-se no cotidiano, problemas decorrentes de falta de atualização e treinamento, implicando diretamente em uma diminuição no rendimento da qualidade da assistência em saúde. Descritores: Educação Continuada em Enfermagem; Enfermagem em Saúde Pública.

\section{RESUMEN}

Objetivo: Analizar las publicaciones que se centran en el proceso de educación continua en enfermería en el período de 2008 a 2011. Método: revisión integradora a cabo en la Biblioteca de Bases de Datos Virtual en Salud (LILACS y SciELO), con los siguientes criterios de inclusión: tener en cuenta su finalidad, año publicación a partir de 2008 a 2011, abordando la cuestión de la formación continua dentro de la Enfermería, tener el texto disponible en línea, en idioma Inglés, portugués o español. Resultados: Después de la búsqueda, fueron analizados y categorizados nueve artículos. Conclusión: se dio cuenta de que los desafíos y las acciones realizadas por el equipo multidisciplinario en la actualidad están relacionados con la falta de acciones de incentivo de Educación Continua. Dentro de la Enfermería son aún más importantes estas acciones, como se observa en la vida cotidiana, los problemas derivados de la falta de actualización y capacitación, lo que implica directamente una disminución en el rendimiento de la calidad de la atención de salud. Descriptores: Educación Continua en Enfermería, Enfermería en Salud Pública.

\footnotetext{
${ }_{1,2,3,4}$ Nursing students in the 6th period of the Graduate Course in Nursing, School of Nursing Aurora de Afonso Costa, Federal Fluminense University - EEAAC / UFF; bruna.barreto07@gmail.com; danieltavaresuff@yahoo.com.br; julianabrandao20@yahoo.com.br; juliana_cpg_1@hotmail.com. ${ }^{5}$ Nurse, Adjunct Professor of the School of Nursing Aurora de Afonso Costa, Federal Fluminense University, PhD in Nursing from the College of Nursing Anna Nery, Federal University of Rio de Janeiro, Advisor. Email: geilsavalente@yahoo.com.br. School of Nursing, Federal Fluminense University. Rua Dr. Celestino - 74 Centro - Niterói RJ Brazil. ${ }^{6}$ Nurse and psychologist from the Federal Fluminense University. On duty of the Sector of Infectious Diseases, University Hospital Antonio Pedro - UFF. Nurse of the Regional Polyclinic Carlos Antonio da Silva - Niterói / RJ.
}

J. res.: fundam. care. online 2013. jul./set. 5(3):85-93 


\section{INTRODUCTION}

One can understand education as a dynamic and continuous process of knowledge construction through the development of free thought and critical-reflexive consciousness, and that, in human relationships, leads to the creation of personal and professional commitment, training for transformation of reality. ${ }^{1}$

Continuing education has been increasingly the target of attention in many health institutions. For the World Health Organization, continuing education is the process that includes all the experiences after the initial training. 2 Is characterized as the set of experiments after the initial training, allowing the worker to maintain, increase or improve your skills, so that this is consistent with the development of their responsibilities, characterizing, competence and individual attribute. It is a set of continuing education practices, aimed at developing the potential for a change in attitudes and behaviors in the cognitive, affective and psychomotor human being, the prospect of transforming their practice. $^{1}$

Nursing is not just a set of specific skills, nor the nurse is only a person trained to perform specific tasks. Nursing is a profession. To be professional and act this way, should be given careful consciously and based on their knowledge. Thus, a profession requires extensive education of those who practice and it is important to have a fundamental and theoretical body of knowledge and skills that generates defined standards. Hence the importance of continuing education becomes a key strategy for updating the professionals who are working in the field, bringing new concepts and knowledge relevant to a safer practice and conscious.

In addition, nurses are educators and potential multipliers of knowledge, which further increases the need for training of these J. res.: fundam. care. online 2013. jul./set. 5(3):85-93 professionals, because in all his actions are inserted elements that will perpetuate, either through a patient, family or professionals team.

Thus, starting from the problem: What is the evidence that exist in the literature about the importance of continuing education in the improvement of nursing professionals? It has as objective: to analyze publications that focus on the process of continuing education in nursing, the main databases in the period from 2008 to 2011, identifying benefits that this process brings education to practice professional health.

The relevance of this study was identified during the Theoretical and Practical Discipline of Nursing in Health Care Management I, when it was realized that the process of Continuing Education at the Municipal Polyclinic in which was held the stage, yet presents itself effective, demonstrating a gap in the process of updating health professionals, but also the interest on their part to catch up. Therefore, it is believed that it is necessary to implement measures of continuing education within the public health, in order to improve, upgrade and qualify health professionals in their own work environment.

\section{METHODOLOGY}

With the aim of facilitating the development of this study, we opted for an Integrative Review. The period of data collection was developed in the following databases of the Virtual Health Library (VHL): Lilacs (Latin American and Caribbean Center on Health Sciences) and SciELO (Scientific Electronic Library Online).

The review is an important resource Integrative practice based on evidence, which is composed and performed from the synthesis of research results related to a specific problem or issue. It is noteworthy that we used the following descriptors: Public Health Nursing and Continuing 
Barreto BMF, Tavares DN, Brandão JL et al.

Education in Nursing. With the Boolean operators AND and OR.

Inclusion criteria were the following references: having regard to its purpose; publication in the period from 2008 to 2011, addressing the issue of continuing education in nursing; necessarily should have the text available online, in Portuguese language, English or Spanish.

Data were categorized by thematic approach the objects of study and content analysis as follows: the presence of the educational issue; possessed the relationship of lifelong education and SUS; possessed Freire's pedagogical proposal, said the importance and need for training; delimited actions essential to the process of continuing education; presence Strategic management; nursing skills; determined the basic conditions for learning.

Additionally, other articles besides those which were selected were used in the context of work. Thus, from this integrative review, there will be a quick and dynamic professionals for the various researchers in the field of health, providing them support their behaviors and decisions.

\section{RESULTS AND DISCUSSION}

648 articles were found, and of these, 9 were selected for analysis.

The nine (9) selected publications are described in Table 1:

\begin{tabular}{|c|c|c|c|}
\hline Authors & Year & Title & Magazine \\
\hline $\begin{array}{l}\text { 1. Lima, } \\
\text { Macedo, } \\
\text { Vidal et } \\
\text { Sá }\end{array}$ & 2009 & $\begin{array}{c}\text { Permanent } \\
\text { education in BLS } \\
\text { and ACLS: impact } \\
\text { on knowledge of } \\
\text { nursing } \\
\text { professionals }\end{array}$ & $\begin{array}{c}\text { Brazilian archives } \\
\text { of Cardiology }\end{array}$ \\
\hline $\begin{array}{l}\text { 2. Munari } \\
\text { et al }\end{array}$ & 2008 & $\begin{array}{l}\text { Laboratory } \\
\text { education as a } \\
\text { tool in the process } \\
\text { of continuing } \\
\text { education of } \\
\text { Nurses Managers }\end{array}$ & $\begin{array}{c}\text { Journal of nursing } \\
\text { of UERJ }\end{array}$ \\
\hline $\begin{array}{l}\text { 3. Silva, } \\
\text { Barlem, } \\
\text { Lunardi et }\end{array}$ & 2008 & $\begin{array}{l}\text { Permanent } \\
\text { education: } \\
\text { working tool of }\end{array}$ & $\begin{array}{c}\text { Science, health } \\
\text { and Care }\end{array}$ \\
\hline
\end{tabular}

J. res.: fundam. care. online 2013. jul./set. 5(3):85-93
Continuing/permanent education...

\begin{tabular}{|c|c|c|c|}
\hline Santos & & $\begin{array}{l}\text { the nurse at the } \\
\text { institution of long } \\
\text { permanence }\end{array}$ & \\
\hline $\begin{array}{l}\text { 4. Braga } \\
\text { et } \\
\text { Melleiro }\end{array}$ & 2009 & $\begin{array}{c}\text { Perception of } \\
\text { nursing staff } \\
\text { about a continuing } \\
\text { education of a } \\
\text { University } \\
\text { Hospital }\end{array}$ & $\begin{array}{c}\text { Journal of school } \\
\text { of nursing of the } \\
\text { University of São } \\
\text { Paulo }\end{array}$ \\
\hline $\begin{array}{l}\text { 5. Silva e } \\
\text { Seiffert }\end{array}$ & 2009 & $\begin{array}{l}\text { Continuing } \\
\text { education in } \\
\text { Nursing: a } \\
\text { methodological } \\
\text { proposal }\end{array}$ & $\begin{array}{l}\text { Brazilian Magazine } \\
\text { of Nursing }\end{array}$ \\
\hline $\begin{array}{l}\text { 6. Silva et } \\
\text { Peduzzi }\end{array}$ & 2009 & $\begin{array}{l}\text { Characterization } \\
\text { of the educational } \\
\text { activities of } \\
\text { nursing workers in } \\
\text { permanent } \\
\text { education optical }\end{array}$ & $\begin{array}{l}\text { Electronic } \\
\text { Magazine of } \\
\text { Nursing }\end{array}$ \\
\hline $\begin{array}{c}7 . \\
\text { Montanha } \\
\text { et Peduzzi }\end{array}$ & 2010 & $\begin{array}{l}\text { Permanent } \\
\text { education in } \\
\text { Nursing: survey of } \\
\text { needs and } \\
\text { expected results } \\
\text { according to the } \\
\text { conception of } \\
\text { workers }\end{array}$ & $\begin{array}{l}\text { The USP School of } \\
\text { nursing magazine }\end{array}$ \\
\hline $\begin{array}{c}8 . \\
\text { Rodrigues, } \\
\text { Vieira et } \\
\text { Torres }\end{array}$ & 2010 & $\begin{array}{c}\text { The proposal of } \\
\text { permanent } \\
\text { education in } \\
\text { health in the } \\
\text { health team in } \\
\text { diabetes mellitus }\end{array}$ & $\begin{array}{l}\text { The USP School of } \\
\text { nursing magazine }\end{array}$ \\
\hline $\begin{array}{l}\text { 9. Kawata } \\
\text { et al }\end{array}$ & 2011 & $\begin{array}{l}\text { Attributes used by } \\
\text { the family health } \\
\text { nurse: approach } \\
\text { to managerial } \\
\text { competence- } \\
\text { building } \\
\text { performances }\end{array}$ & $\begin{array}{l}\text { The USP School of } \\
\text { nursing magazine }\end{array}$ \\
\hline
\end{tabular}

In order to achieve the objectives of the study, after study analysis were created the following categories:

\section{A. The task in Nursing Education:}

The educational approach is designed to work learning, where learning and teaching is incorporated into the daily life of organizations and work. In this, it proposes an educational process, which is based on meaningful learning. Because, prospects that continuing education seeks to transform the professional practice through responses constructed from the reflection of workers, students and other social actors. Thus, this proposal can be understood as 'learning-work' 
as it happens from the daily lives of people and organizations. ${ }^{4}$

At frame 2 presents a summary of the items that are included in this category:

\begin{tabular}{|c|c|}
\hline $\begin{array}{l}\text { Article } 1 \\
\text { Lima, } \\
\text { Macedo, } \\
\text { Vidal et } \\
\text { Sá, 2009. }\end{array}$ & $\begin{array}{l}\text { Points out that there are flaws in the teaching- } \\
\text { learning process, both in the theoretical } \\
\text { knowledge, and technical skills. In addition to } \\
\text { this, the large time gap between basic training } \\
\text { and professional practice. Corroborate, thus, } \\
\text { educational actions for improving the level of } \\
\text { knowledge of professionals to raise the success } \\
\text { rate in cardiopulmonary resuscitation. }\end{array}$ \\
\hline $\begin{array}{l}\text { ticle } 2 \\
\text { unari et } \\
2008\end{array}$ & $\begin{array}{l}\text { Continuing education not only works as a focus } \\
\text { to subordinates, but also as a way to improve } \\
\text { the managerial skills of the nurse. In addition, } \\
\text { as organizations are not always professionals } \\
\text { with managerial profile desired, choose to } \\
\text { invest in continuing training of their managers. }\end{array}$ \\
\hline $\begin{array}{l}\text { Article } 3 \\
\text { Silva, } \\
\text { Barlem, } \\
\text { Lunardi et } \\
\text { Santos, } \\
2008\end{array}$ & $\begin{array}{l}\text { This is the Nursing Education widely, referring } \\
\text { to formal education in technical courses, } \\
\text { undergraduate and graduate students or health } \\
\text { education geared to training in service. }\end{array}$ \\
\hline $\begin{array}{l}\text { Article } 4 \\
\text { Braga et } \\
\text { Melleiro, } \\
2009\end{array}$ & $\begin{array}{l}\text { Points out that in nursing, the responsibility to } \\
\text { upgrade and train professionals is related to } \\
\text { the SEC (continuing education). The nurse, who } \\
\text { plays in the SEC must integrate the nursing } \\
\text { staff so that it can empower and employ their } \\
\text { actions, stimulating the professional } \\
\text { development. }\end{array}$ \\
\hline $\begin{array}{l}\text { Article } 5 \\
\text { Silva e } \\
\text { Seiffert, } \\
2009\end{array}$ & $\begin{array}{l}\text { Permanent education of nursing professionals is } \\
\text { directly related to the daily work, this being } \\
\text { the axis of the educational process, source of } \\
\text { knowledge transformation object and should } \\
\text { give priority to the collective and } \\
\text { interdisciplinary participation. }\end{array}$ \\
\hline $\begin{array}{l}\text { Article } 7 \\
\text { Montanha } \\
\text { et } \\
\text { Peduzzi, } \\
2010\end{array}$ & $\begin{array}{l}\text { nat the educational activities in health } \\
\text { red mostly to problems identified in } \\
\text { lainly in technical nursing procedures. } \\
\text { t continuing education is the kind of } \\
\text { on that appears in the field of nursing. }\end{array}$ \\
\hline $\begin{array}{l}\text { Article } 8 \\
\text { Rodrigues, } \\
\text { Vieira et } \\
\text { Torres, } \\
2010\end{array}$ & $\begin{array}{l}\text { By conducting a seminar was presented a } \\
\text { proposal for action to the service for people } \\
\text { with Diabetes, opening a space to the issue of } \\
\text { permanent education and draw the attention } \\
\text { of the health care team regarding the } \\
\text { educational program on Diabetes Mellitus } 2\end{array}$ \\
\hline
\end{tabular}

It appears from the material analyzed, the goal of education is not instill much information that a person is able to acquire, but to create a reflective subject, which can from the acquisition of knowledge, permeate their actions consciously and thinking.

\section{B. The Permanent Education as a strategy for improving SUS}

While pedagogical concept for health, lifelong education works with the organic relations between education and the services provided, and between teaching and health care. From Health J. res.: fundam. care. online 2013. jul./set. 5(3):85-93
Reform, there was an expansion of the meaning of this process, focusing on the relationship between training and sector management, institutional development and social control in health as instruments for continuous learning. ${ }^{5}$

Frame 3 presents a summary of the items that are included in this category:

\begin{tabular}{|c|c|}
\hline $\begin{array}{l}\text { Article } 1 \\
\text { Lima, } \\
\text { Macedo, } \\
\text { Vidal et } \\
\text { Sá, 2009. }\end{array}$ & $\begin{array}{l}\text { Does not address the permanent education in } \\
\text { public health, however, points out that in a } \\
\text { cardiopulmonary arrest, nursing professionals } \\
\text { are the first to provide specific and } \\
\text { emergency care, therefore, require intense } \\
\text { continuing training for the success of the } \\
\text { necessary procedures. }\end{array}$ \\
\hline $\begin{array}{l}\text { Article } 2 \\
\text { Munari et } \\
\text { al, } 2008\end{array}$ & $\begin{array}{l}\text { Discusses the position of nurses who work in } \\
\text { the management of nursing services in } \\
\text { hospitals, being of paramount importance to } \\
\text { search for specific skills to meet the demands } \\
\text { of hospital organizations, which encompasses } \\
\text { the requirements of users, of institutions and } \\
\text { of workers. }\end{array}$ \\
\hline $\begin{array}{l}\text { Article } 3 \\
\text { Silva, } \\
\text { Barlem, } \\
\text { Lunardi et } \\
\text { Santos, } \\
2008\end{array}$ & $\begin{array}{l}\text { Addresses the permanent education as } \\
\text { learning at work. It is a challenge to establish } \\
\text { themselves in a transformer, a resource } \\
\text { mobilization strategy for strengthening of the } \\
\text { SUS. It focuses on the permanent education } \\
\text { in the basic attention, but in long-stay } \\
\text { Institutions, while stressing the importance } \\
\text { of such strategies in all areas of health. }\end{array}$ \\
\hline $\begin{array}{l}\text { Article } 4 \\
\text { Braga et } \\
\text { Melleiro, } \\
2009\end{array}$ & $\begin{array}{l}\text { Does not reflect the permanent education } \\
\text { linked to SUS, as well as in the core network, } \\
\text { but develops the research within a private } \\
\text { non-profit university hospital, highlighting } \\
\text { the complexity of analysis of SEC in a } \\
\text { healthcare organization. }\end{array}$ \\
\hline $\begin{array}{l}\text { Article } 6 \\
\text { Silva et } \\
\text { Peduzzi, } \\
2009\end{array}$ & $\begin{array}{l}\text { States that in the field of health and nursing } \\
\text { education activities are covered under the } \\
\text { permanent education adopted by the Ministry } \\
\text { of health, and this is a public policy for } \\
\text { professional development for the SUS. }\end{array}$ \\
\hline $\begin{array}{l}\text { Article } 7 \\
\text { Montanha } \\
\text { et } \\
\text { Peduzzi, } \\
2010\end{array}$ & $\begin{array}{l}\text { Reports on the creation of permanent } \\
\text { education in health policy, drawn up by the } \\
\text { Ministry of health, with the aim of improving } \\
\text { the health services offered by the health care } \\
\text { network in the country. }\end{array}$ \\
\hline $\begin{array}{l}\text { Article } 8 \\
\text { Rodrigues, } \\
\text { Vieira et } \\
\text { Torres, } \\
2010 \\
\end{array}$ & $\begin{array}{l}\text { Shows that the national policy of permanent } \\
\text { education in health was a proposal of the } \\
\text { Ministry of health to be the education policy } \\
\text { of the SUS and transform the public network } \\
\text { in an area of teaching and learning at work. }\end{array}$ \\
\hline $\begin{array}{l}\text { Article } 9 \\
\text { Kawata et } \\
\text { al, } 2011\end{array}$ & $\begin{array}{l}\text { States that the policy of permanent } \\
\text { education in the SUS, says education service } \\
\text { as a strategic resource to labour and } \\
\text { management as a strategy for recovery of } \\
\text { training practices and attention. }\end{array}$ \\
\hline
\end{tabular}

Based on productions presented, it appears that actions, education and health services should be integrated because they are important to enhance the management process and management, in addition to appropriate social control for qualification of manpower and practices health.

\section{The pedagogical propost by Freire}


Frame 4 presents a summary of the items that are included in this category:

\begin{tabular}{|c|c|}
\hline $\begin{array}{l}\text { Article } 3 \\
\text { Silva, } \\
\text { Barlem, } \\
\text { Lunardi } \\
\text { et } \\
\text { Santos, } \\
2008\end{array}$ & $\begin{array}{l}\text { Aproximates permanent education with } \\
\text { problematical and liberating education of } \\
\text { Freire, because its pedagogical proposal } \\
\text { forms critical individuals through } \\
\text { significant changes of practice. Intends to } \\
\text { overcome the contradiction educator- } \\
\text { students, so that they are both at the } \\
\text { same time, educators and students. }\end{array}$ \\
\hline $\begin{array}{c}\text { Article } 7 \\
\text { Montanha } \\
\text { et } \\
\text { Peduzzi, } \\
2010\end{array}$ & $\begin{array}{l}\text { Cites Freire as a great contribution to the } \\
\text { foundation of permanent education, } \\
\text { especially with regard to the concept of } \\
\text { fundamental education and meaningful } \\
\text { learning, which takes into account the } \\
\text { knowledge and experiences that people } \\
\text { have. }\end{array}$ \\
\hline
\end{tabular}

Thus, education is to empower individuals to take responsibility in the world, share ideas and methodologies that make them competent and abilities to act in different situations. It also send and exchange information, discuss positive and negative aspects, ethical, social and cultural dimensions among others, is to train people capable of changing the social context.

\section{Training needs}

With the many ways to improve technicalscientific, the nurse must be alert to the changing needs of health, taking into account not only injuries or prevention measures, but also the general conditions in which the population lives. Therefore, it is justified to ongoing professional development in order to prevent the knowledge gap and promote health care quality.

Frame 5 presents a summary of the items that are included in this category:

\begin{tabular}{|c|l|}
\hline $\begin{array}{c}\text { Article 1 } \\
\text { Lima, } \\
\text { Macedo, } \\
\text { Vidal et } \\
\text { Sá, 2009. }\end{array}$ & $\begin{array}{l}\text { Reveals that nursing professionals do not have a } \\
\text { qualified performance in CPR actions, } \\
\text { therefore, require continuous training to ensure } \\
\text { the success of the procedure and recovery of } \\
\text { clients who need this kind of support. }\end{array}$ \\
\hline $\begin{array}{c}\text { Article 2 } \\
\text { Munari et } \\
\text { al, 2008 }\end{array}$ & $\begin{array}{l}\text { Nurse managers need to acquire specific skills } \\
\text { to integrate and manage work teams, optimize } \\
\text { productivity and enhance the continuity of } \\
\text { projects deployed. The main objective is to } \\
\text { accelerate the process of humanization of care, } \\
\text { improving the quality of care and health of } \\
\text { health professionals. }\end{array}$ \\
\hline $\begin{array}{c}\text { Article 3 } \\
\text { Silva, } \\
\text { Barlem, } \\
\text { Lunardi }\end{array}$ & $\begin{array}{l}\text { process and the quality of work in health } \\
\text { services, which includes direct nursing in its } \\
\text { goal to improve attention. It is necessary to } \\
\text { have critical and innovative individuals who } \\
\text { Santos, } \\
\text { exceed the traditional conceptions of } \\
\text { education. }\end{array}$
\end{tabular}

\begin{tabular}{|c|l|}
\hline $\begin{array}{c}\text { Article 4 } \\
\text { Braga et } \\
\text { Melleiro, } \\
2009\end{array}$ & $\begin{array}{l}\text { The SEC draws up his training schedule with the } \\
\text { team of nursing professionals, so that they can } \\
\text { show their acquisition needs and deepening of } \\
\text { knowledge with some themes. }\end{array}$ \\
\hline $\begin{array}{c}\text { Article 5 } \\
\text { Silva e } \\
\text { Seiffert, } \\
2009\end{array}$ & $\begin{array}{l}\text { Nurses survey respondents believe that the need } \\
\text { of continuing education is linked to the } \\
\text { advancement and renewal of technology, } \\
\text { knowledge and integration of the new vision for } \\
\text { nursing and medical work. }\end{array}$ \\
\hline $\begin{array}{c}\text { Artigo 7 } \\
\text { Montanha } \\
\text { et }\end{array}$ & $\begin{array}{l}\text { Points out the health needs of the users and the } \\
\text { survey of the needs of educational workers, are } \\
\text { the core of the educational process in health. }\end{array}$ \\
Peduzzi, & $\begin{array}{l}\text { Agree that the educational processes must be } \\
\text { based on the needs of the population-triad- } \\
\text { service workers. }\end{array}$ \\
\hline
\end{tabular}

As the authors mentioned above, it appears that the importance of updating knowledge is present in any area, with greater importance to health, to the detriment of relations of life and death. In addition, there will be the prevention of risks arising from lack of training, which acts as a stimulus for the performance of critical and innovative teaching-learning process.

\section{E. Essential actions to the process of permanent education}

The concept of continuing health education was initially worked in the health organization Pan-American Health Organization (PAHO), in Brazil, was established as a public policy, which is understood as "learning on the job, where learning and teaching are incorporated into the organizations and everyday to work. "Its realization depends on the educational processes of health workers have as their objective the transformation of professional practices and the organization of work ${ }^{6}$

Frame 6 presents a summary of the items that are included in this category:

\begin{tabular}{|c|c|}
\hline $\begin{array}{l}\text { Article } 1 \\
\text { Lima, } \\
\text { Macedo, } \\
\text { Vidal et } \\
\text { Sá, } 2009 .\end{array}$ & $\begin{array}{l}\text { Allocate } 50 \% \text { of the total time to train practical } \\
\text { skills, because it makes the learning more } \\
\text { meaningful and contextualized. However, the } \\
\text { effectiveness of this strategy of education and } \\
\text { continuing training, motivation is essential, } \\
\text { because the performance be improved, there } \\
\text { must be motivation to participate. }\end{array}$ \\
\hline $\begin{array}{l}\text { Article } 2 \\
\text { Munari et } \\
a l, 2008\end{array}$ & $\begin{array}{l}\text { Competencies as set of knowledge, skills and } \\
\text { attitudes. Motivation and commitment are also } \\
\text { aspects that drive employees to a satisfactory } \\
\text { development of its activities, in addition to } \\
\text { partnership and mutual collaboration between } \\
\text { Coordinator and participant, and the } \\
\text { participant and participant. }\end{array}$ \\
\hline $\begin{array}{l}\text { Article } 3 \\
\text { Silva, } \\
\text { Barlem, } \\
\text { Lunardi et } \\
\text { Santos, } \\
2008\end{array}$ & $\begin{array}{l}\text { Actions in the areas of technical training, } \\
\text { undergraduate and the graduate, the } \\
\text { organisation of work, interaction with the } \\
\text { networks and management of health services } \\
\text { and social control in this sector. }\end{array}$ \\
\hline
\end{tabular}

J. res.: fundam. care. online 2013. jul./set. 5(3):85-93 


\begin{tabular}{|c|c|}
\hline $\begin{array}{l}\text { Article } 4 \\
\text { Braga et } \\
\text { Melleiro, } \\
2009\end{array}$ & $\begin{array}{l}\text { The approach of the contents must be } \\
\text { contextualized in the reality of the health } \\
\text { institution, considering the work routine, the } \\
\text { industry and the needs of the professional, so } \\
\text { that the structure, physical and material } \\
\text { resources, timetables and training duration and } \\
\text { contents covered are consistent with the } \\
\text { situation of the unit. }\end{array}$ \\
\hline $\begin{array}{l}\text { ticle } 5 \\
\text { va e } \\
\text { iffert, } \\
09\end{array}$ & $\begin{array}{l}\text { There must be investment in infrastructure and } \\
\text { in the continuing education staff; encourage } \\
\text { research and study; forms of dissemination of } \\
\text { programs and interdisciplinary interaction. }\end{array}$ \\
\hline $\begin{array}{l}\text { Article } 7 \\
\text { Montanha } \\
\text { et } \\
\text { Peduzzi, } \\
2010\end{array}$ & $\begin{array}{l}\text { The value of the work as a source of } \\
\text { knowledge; search for articulation of } \\
\text { educational processes of workers with the } \\
\text { everyday work processes, as well as the search } \\
\text { for articulation with the health care, } \\
\text { management and social control; the } \\
\text { recognition that the practices are defined by } \\
\text { multiple factors and dimensions; the } \\
\text { orientation of the educational activities of } \\
\text { workers for the integration of multidisciplinary } \\
\text { and interdisciplinary teamwork; the use of } \\
\text { contextualized and participative teaching } \\
\text { strategies and the search for the } \\
\text { transformation of health and nursing practices. }\end{array}$ \\
\hline $\begin{array}{l}\text { Article } 8 \\
\text { Rodrigues, } \\
\text { Vieira et } \\
\text { Torres, } \\
2010\end{array}$ & $\begin{array}{l}\text { The critical reflection on the problems } \\
\text { concerning the quality of care, discussing the } \\
\text { educational activities in diabetes that need to } \\
\text { be modified to improve the practice of health } \\
\text { professionals who work in the program, making } \\
\text { them able to build health actions. }\end{array}$ \\
\hline
\end{tabular}

The continuing health education is through the articulation between theory and practice performed by subject-workers, based on institutional policies that support these actions. In this sense, we visualized the possibilities of change through the actions of continuing health education can be incorporated into alternative ways to transcend traditional modes of education.

\section{F. Strategic Management}

The strategic management relates to strategic planning, which are set priorities for action and action profile for the entire organization in order to achieve long-term results. $^{7}$

Frame 7 presents a summary of the items that are included in this category:

\begin{tabular}{|l|l|}
\hline $\begin{array}{l}\text { Article 2 } \\
\text { al, 2008 }\end{array}$ & $\begin{array}{l}\text { To ensure desired results, in actuality, the } \\
\text { hospitals need to qualify professionals to } \\
\text { management, leadership and negotiation. } \\
\text { Strategic management, there is the need for } \\
\text { investment in changing organizational culture, } \\
\text { focused on collective process. }\end{array}$ \\
\hline $\begin{array}{l}\text { Article 3 } \\
\text { Silva, } \\
\text { Barlem, } \\
\text { Lunardi } \\
\text { et }\end{array}$ & $\begin{array}{l}\text { Taking into consideration the overhead } \\
\text { needs to be thought out and carefully planned. }\end{array}$ \\
\hline
\end{tabular}

J. res.: fundam. care. online 2013. jul./set. 5(3):85-93

\begin{tabular}{|c|c|}
\hline $\begin{array}{l}\text { Santos, } \\
2008\end{array}$ & is dialogue. \\
\hline $\begin{array}{l}\text { Article } 4 \\
\text { Braga et } \\
\text { Melleiro, } \\
2009\end{array}$ & $\begin{array}{l}\text { Is centered in the SEC, which must nurse act } \\
\text { as an agent of change, and develop their } \\
\text { strategies of empowerment and integration of } \\
\text { nursing staff. }\end{array}$ \\
\hline $\begin{array}{l}\text { Article } 5 \\
\text { Silva e } \\
\text { Seiffert, } \\
2009\end{array}$ & $\begin{array}{l}\text { Encompasses the planning context, vision and } \\
\text { interdisciplinary practice, adequate } \\
\text { infrastructure, communication and } \\
\text { involvement of line managers and partnership } \\
\text { with other healthcare institutions. }\end{array}$ \\
\hline $\begin{array}{l}\text { Article } 6 \\
\text { Silva et } \\
\text { Peduzzi, } \\
2009\end{array}$ & $\begin{array}{l}\text { Corresponds, in research, the activities } \\
\text { related to the management of the unit, of } \\
\text { materials, human resources, information } \\
\text { systems and users. }\end{array}$ \\
\hline $\begin{array}{l}\text { Article } 7 \\
\text { Montanha } \\
\text { et } \\
\text { Peduzzi, } \\
2010\end{array}$ & $\begin{array}{l}\text { See Managing the key piece for the efficiency, } \\
\text { efficacy and effectiveness of health services. }\end{array}$ \\
\hline $\begin{array}{l}\text { Article } 9 \\
\text { Kawata } \\
\text { et al, } \\
2011\end{array}$ & $\begin{array}{l}\text { See on family health, a public policy strategy } \\
\text { reorientation of services. Considers the } \\
\text { management a strategic dimension to the } \\
\text { process of transformation work, understood as } \\
\text { a tool that directs the work process for the } \\
\text { production of care. }\end{array}$ \\
\hline
\end{tabular}

It is through action planning and management that nursing can build an organized care and quality, since these processes involve not only administrative functions, but also permits the design of development strategies and training of professionals working in care.

\section{G. Nursing Skills}

To have a professional responsibility, it is necessary to acquire knowledge, skills, and have attitudes, because then he will have the basics to start their actions on their skills and techniques geared to their knowledge. But that knowledge to generate skills, the knowledge that is needed to be mobilized through schemes of action, arising out of schemes of perception, decision and evaluation, developed in practice. ${ }^{8}$

Frame 8 presents a summary of items that are included in this category:

\begin{tabular}{|l|l|}
\hline $\begin{array}{l}\text { Article 2 } \\
\text { Munari et } 2008\end{array}$ & $\begin{array}{l}\text { Demystifying defends leadership as a skill or a } \\
\text { talent, but as a set of skills that can be } \\
\text { acquired, i.e., the result of the combination of } \\
\text { knowledge, skills and attitudes that can be } \\
\text { developed. }\end{array}$ \\
\hline $\begin{array}{l}\text { Article 4 } \\
\text { Braga et } \\
\text { Melleiro, } \\
2009\end{array}$ & $\begin{array}{l}\text { Mentions the importance of updating and } \\
\text { improvement of nursing through the changes } \\
\text { and advancements in the field of science and } \\
\text { technology to the need of these professionals } \\
\text { in their work. }\end{array}$ \\
\hline $\begin{array}{l}\text { Article 5 } \\
\text { Silva } \\
\text { Seiffert, e } \\
2009\end{array}$ & $\begin{array}{l}\text { For the Pan-American Health Organization } \\
\text { (PAHO), the professional nurse must be the } \\
\text { industrys continuing education Coordinator, } \\
\text { being directly involved with the personal and } \\
\text { professional development needs of the team. }\end{array}$ \\
\hline
\end{tabular}




\begin{tabular}{l|l|}
$\begin{array}{l}\text { Article 7 } \\
\text { Montanha } \\
\text { et } \\
\begin{array}{l}\text { Peduzzi, } \\
2010\end{array}\end{array}$ & $\begin{array}{l}\text { The reports from nurses and managers on the } \\
\text { supervisory action, which is meant as inherent } \\
\text { in the work process of nurses is referred to as a } \\
\text { source to detect needs requiring educational } \\
\text { activities. }\end{array}$ \\
$\begin{array}{l}\text { Article 8 } \\
\text { Rodrigues, } \\
\text { Vieira et } \\
\begin{array}{l}\text { Torres, } \\
\text { 2010 }\end{array}\end{array}$ & $\begin{array}{l}\text { The article highlights, at various times, the } \\
\text { educator that the nurse has potential and its } \\
\text { importance in the Diabetes education program. }\end{array}$ \\
$\begin{array}{l}\text { Article 9 } \\
\text { Kawata et } \\
\text { al, 2011 }\end{array}$ & $\begin{array}{l}\text { See the supervision as an instrument of control } \\
\text { and education, pointing out that the } \\
\text { supervision is part of the collective process of } \\
\text { work on health. }\end{array}$ \\
\hline
\end{tabular}

It is noteworthy, then, that nurses need to acquire skills and develop them throughout their professional life, especially the leadership, coupled with the profile educator, will make the process of continuing education feasible, achieving greater quality and improvement of care.

\section{H. Basic Conditions of Learning}

The good development of educational activities depends on a number of factors that directly interfere with the learning of individuals. These factors are related not only with teaching activities themselves but also permeate the physical and material resources they require.

\begin{tabular}{|c|c|}
\hline $\begin{array}{l}\text { cle } 1 \\
\text { a, } \\
\text { edo, } \\
\text { al et Sá, } \\
9 .\end{array}$ & $\begin{array}{l}\text { Hourly charges, poor remuneration and strenuous } \\
\text { double journey, and the lack of material for the } \\
\text { realization of procedures so that time compete } \\
\text { for retraining is reduced. }\end{array}$ \\
\hline $\begin{array}{l}\text { Article } 2 \\
\text { Munari et } \\
\text { al, } 2008\end{array}$ & $\begin{array}{l}\text { The infrastructure, communication, team } \\
\text { motivation, recognition, limitations of the lack of } \\
\text { strategies to integrate the team, perform an } \\
\text { operational planning, establish link between your } \\
\text { staff and workers seek collective commitment, } \\
\text { are difficult elements to implement of } \\
\text { presupposed humanization of care. }\end{array}$ \\
\hline $\begin{array}{l}\text { Article } 3 \\
\text { Silva, } \\
\text { Barlem, } \\
\text { Lunardi et } \\
\text { Santos, } \\
2008\end{array}$ & $\begin{array}{l}\text { Many nursing courses still have no } \\
\text { materials/content that instrumentalyze future } \\
\text { nurses to the care to the elderly. Soon, develop } \\
\text { permanent education in long-stay institutions, due } \\
\text { to the overload of activities, it becomes a very } \\
\text { difficult task that needs to be planned. }\end{array}$ \\
\hline ro, & $\begin{array}{l}\text { e duration of training should be seen as very } \\
\text { g courses tend to be unproductive; the time } \\
\text { s appointed as the main difficulty in adherence } \\
\text { training actions. }\end{array}$ \\
\hline $\begin{array}{l}\text { Article } 5 \\
\text { Silva e } \\
\text { Seiffert, } \\
2009\end{array}$ & $\begin{array}{l}\text { For there to be continuing education for nursing } \\
\text { professionals must be dynamic, participative } \\
\text { planning, with defined objectives, in order to } \\
\text { meet the needs of the institution and } \\
\text { professionals. }\end{array}$ \\
\hline $\begin{array}{l}\text { e } 7 \\
\text { anha } \\
\text { duzzi, }\end{array}$ & $\begin{array}{l}\text { The issue of learning becomes scarce due to the } \\
\text { lack of references on survey of the needs of } \\
\text { educational workers. }\end{array}$ \\
\hline $\begin{array}{l}\text { Article } 8 \\
\text { Rodrigues, } \\
\text { Vieira et } \\
\text { Torres, } \\
2010\end{array}$ & $\begin{array}{l}\text { Works the permanent education in health as a } \\
\text { discipline curriculum activity such as supervised } \\
\text { internship. }\end{array}$ \\
\hline $\begin{array}{l}\text { Article } 9 \\
\text { Kawata et } \\
\text { al, } 2011\end{array}$ & $\begin{array}{l}\text { Observe what types of technologies are being } \\
\text { adopted by nurses in family health and provide } \\
\text { subsidies for construction of educational projects } \\
\text { relating to the training of nurses with knowledge, } \\
\text { skills, and attitudes contemporary in the context } \\
\text { of Sistema Único de Saúde - SUS. }\end{array}$ \\
\hline
\end{tabular}

\begin{tabular}{|c|c|}
\hline $\begin{array}{l}\text { Article } 1 \\
\text { Lima, Macedo, } \\
\text { Vidal et Sá, } \\
\text { 2009. }\end{array}$ & $\begin{array}{l}\text { Hourly charges, poor remuneration and strenuous double journey, and the lack of material for the realization of procedures so } \\
\text { that time compete for retraining is reduced. }\end{array}$ \\
\hline $\begin{array}{l}\text { Article } 2 \\
\text { Munari et al, } \\
2008\end{array}$ & $\begin{array}{l}\text { The infrastructure, communication, team motivation, recognition, limitations of the lack of strategies to integrate the team, } \\
\text { perform an operational planning, establish link between your staff and workers seek collective commitment, are difficult } \\
\text { elements to implement of presupposed humanization of care. }\end{array}$ \\
\hline $\begin{array}{l}\text { Article } 3 \\
\text { Silva, Barlem, } \\
\text { Lunardi et } \\
\text { Santos, } 2008\end{array}$ & $\begin{array}{l}\text { Many nursing courses still have no materials/content that instrumentalyze future nurses to the care to the elderly. Soon, } \\
\text { develop permanent education in long-stay institutions, due to the overload of activities, it becomes a very difficult task that } \\
\text { needs to be planned. }\end{array}$ \\
\hline $\begin{array}{l}\text { Article } 4 \\
\text { Braga et } \\
\text { Melleiro, } 2009\end{array}$ & $\begin{array}{l}\text { The duration of training should be seen as very long courses tend to be unproductive; the time was appointed as the main } \\
\text { difficulty in adherence to training actions. }\end{array}$ \\
\hline $\begin{array}{l}\text { Article } 5 \\
\text { Silva e Seiffert, } \\
2009\end{array}$ & $\begin{array}{l}\text { For there to be continuing education for nursing professionals must be dynamic, participative planning, with defined } \\
\text { objectives, in order to meet the needs of the institution and professionals. }\end{array}$ \\
\hline $\begin{array}{l}\text { Article } 7 \\
\text { Montanha et } \\
\text { Peduzzi, } 2010\end{array}$ & The issue of learning becomes scarce due to the lack of references on survey of the needs of educational workers. \\
\hline $\begin{array}{l}\text { Article } 8 \\
\text { Rodrigues, } \\
\text { Vieira } \\
\text { Torres, } 2010\end{array}$ & Works the permanent education in health as a discipline curriculum activity such as supervised internship. \\
\hline $\begin{array}{l}\text { Article } 9 \\
\text { Kawata et al, } \\
2011\end{array}$ & $\begin{array}{l}\text { Observe what types of technologies are being adopted by nurses in family health and provide subsidies for construction of } \\
\text { educational projects relating to the training of nurses with knowledge, skills, and attitudes contemporary in the context of } \\
\text { Sistema Único de Saúde - SUS. }\end{array}$ \\
\hline
\end{tabular}

J. res.: fundam. care. online 2013. jul./set. 5(3):85-93 
Barreto BMF, Tavares DN, Brandão JL et al.

There is then the need to consider the process of teaching and learning a complex process that involves many issues beyond the educational activity. This depends on good organization and proper planning, which reflects the need of human, physical and material sufficient for proper course of action.

\section{CONCLUSION}

In fact, it is easily understood that the challenges and actions by the multidisciplinary team at present are related to the lack of incentive shares of Continuing Education. Within the Nursing are even more essential these actions, because if they have observed problems related to lack of updating and training, directly implying a decrease in the yield of the quality of care.

Therefore, it is very important the process of Continuing Education in the various professions, including nursing, because there is the possibility to improve, update and upgrade their knowledge from more knowledge that will later be put into practice, resulting in greater competence to perform a particular function.

It is known that there is still a long way for the lag decreases technical and scientific knowledge, the previous guidance provided by health institutions to be effective, among other resources, particularly in relation to Public Health. However, when this body of knowledge, information and interactions occur, nursing becomes increasingly effective and strong, thus making the health care happen effectively.

Continuing education, in general, still faces obstacles as temporary contracts, because as the employee does not have the type of employment, intensified the limitations to the effectiveness of this process, gaining greater magnitude, when there is no presence of nurses in the management of government programs.

In addition, health professionals should be encouraged and motivated to catch up with the J. res.: fundam. care. online 2013. jul./set. 5(3):85-93
Continuing/permanent education...

goal of generating higher quality care, effective care and promoting a particular customer.

\section{REFERENCES}

1. Paschoal AS, Mantovani MF, Méier MJ. Percepção da educação permanente, continuada e em serviço para enfermeiros de um hospital de ensino. Revista Escola de Enfermagem da USP. 2007; 41(3): 478-84. Available from: http: / /www.scielo.br/pdf/reeusp/v41n3/19.pdf.

2. Girade MG, Cruz EMNT, Stefanelli MC. Educação continuada em enfermagem psiquiátrica: reflexão sobre conceitos. Revista da Escola de Enfermagem da USP. 2006; 40(1): 105-10. Available from: http://www.scielo.br/pdf/reeusp/v40n1/a14v40n 1.pdf.

3. Potter PA, Perry AG. Fundamentos de Enfermagem: Conceitos, Processos e Práticas. $7^{\mathrm{a}}$ edição. Rio de Janeiro: Guanabara Koogan; 2009; p. 7.

4. Silva LAA, Franco GP, Leite MT, Pinno C, Lima VML, Saraiva N. Concepções educativas que permeiam os planos regionais de educação permanente. Texto e contexto. 2011; 20(2) Available from: http: / / www.scielo.br/scielo.php?script=sci_arttex t\&pid=S010407072011000200017\&ng=pt\&nrm=iso.

5. Portaria No 198/GM/MS. Em 13 de fevereiro de 2004. Available from: http://portal.saude.gov.br/portal/arquivos/pdf/p ortariagm198polos.pdf.

6. Silva LAA, Ferraz F, Lino MM, Backes VMS, Schmidt SMS. Educação permanente em saúde e no trabalho de enfermagem: perspectiva de uma práxis transformadora. Revista Gaúcha de Enfermagem. 2010; 31(3) Available from: http://www.scielo.br/pdf/rgenf/v31n3/v31n3a21. pdf.

7.Advocacia Geral da União. O que é gestão estratégica? Available from: http://www.agu.gov.br/sistemas/site/TemplateT 
Barreto BMF, Tavares DN, Brandão JL et al.

exto.aspx?idConteudo=81196\&ordenacao=1\&id_sit $e=1360$.

8. Perrenoud P. Dez novas competências para ensinar. $1^{a}$ edição. São Paulo: Artmed; 2000.

9. Lima SG, Macedo LA, Vidal ML, Sá MPBO. Educação Permanente em SBV e SAVC: impacto no conhecimento dos profissionais de enfermagem. Arquivo Brasileiro de Cardiologia. 2009. 93(6). Available

from

http: / / www.scielo.br/scielo.php?script=sci_arttex t\&pid=S0066782X2009001200012\&ang=pt\&tlng=pt.

10. Munari DB, Nunes FC, Motta KAMB, Esperidião

E, Silva JI, Coelho MA. Educação de Laboratório como Ferramenta no Processo de Educação Continuada de Enfermeiros Gerentes. Revista de Enfermagem da UERJ. 2008. 16(4): 577-83. Available from http://files.bvs.br/upload/S/01043552/2008/v16n4/a577-583.pdf.

11. Silva BT, Barlem ELD, Lunardi VL, Santos SSC. Educação Permanente: Instrumento de Trabalho do Enfermeiro na Instituição de Longa Permanência. Ciência Cuidado e Saúde. 2008. 7(2): 256-61. Available from http://www.periodicos.uem.br/ojs/index.php/Cie ncCuidSaude/article/view/5015/3249.

12. Braga AT, Melleiro MM. Percepção da equipe de enfermagem acerca de um serviço de educação continuada de um Hospital Universitário. Revista Escola de Enfermagem da USP. 2009. 43(2). Available from: http: / / www.scielo.br/scielo.php?script=sci_arttex t\&pid=S008062342009000600012\&lang=pt\&tlng=pt.

13. Silva GM, Seiffert OMLB. Educação continuada em enfermagem: uma proposta metodológica. Resvita Brasileira de Enfermagem. 2009. 62(3). Available

from: http: / / www.scielo.br/scielo.php?script=sci_arttex t\&pid=S0034-71672009000300005\&tlng=pt.

14. Silva $\mathbf{A} M$, Peduzzi M. Caracterização das atividades educativas de trabalhadores de enfermagem na ótica da educação permanente. Revista Eletrônica de Enfermagem. 2009. 11(3):

J. res.: fundam. care. online 2013. jul./set. 5(3):85-93
Continuing/permanent education...

518-26.

Available

from:

http://www.fen.ufg.br/revista/v11/n3/v11n3a08. htm.

15. Montanha D, Peduzzi M. Educação permanente em enfermagem: levantamento de necessidades e resultados esperados segundo a concepção dos trabalhadores. Revista Escola de Enfermagem da USP. 2010. 44(3). Available from: http: / / www.scielo.br/scielo.php?script=sci_arttex t\&pid=S008062342010000300007\&lang=pt\&tlng=pt. 16. Rodrigues ACS, Vieira GLC, Torres HC. A proposta de Educação permanente em saúde na atualização da equipe de saúde em diabetes mellitus. Revista da Escola de Enfemagem da USP. 2010. 44(2). Available from: http: / / www.scielo.br/scielo.php?script=sci_arttex t\&pid=S008062342010000200041\&ang=pt\&tlng=pt. 17. Kawata LS, Mishima SM, Chirelli MQ, Pereira MJB, Matumoto S, Fortuna CM. Atributos mobilizados pela enfermeira na Saúde da Família: aproximação aos desempenhos na construção da competência gerencial. Revista Escola Enfermagem da USP. 2011. 45(2). Available from: http: / / www.scielo.br/scielo.php?script=sci_arttex t\&pid=S008062342011000200007\&lng=pt.

Received on: $28 / 10 / 2011$

Reviews required: No

Approved on: 21/03/2013

Published on: 01/07/2013 